\title{
Kebijakan Peraturan OJK Terhadap Perbankan Syariah dalam Menghadapi Wabah Covid-19 di Era New Normal
}

\author{
Inna Fauzi ${ }^{1}$, Yassirlana Anjani ${ }^{2}$ \\ IAIN Kudus ${ }^{1}$, IAIN Kudus ${ }^{2}$ \\ innafauzi@iainkudus.ac.id1, yassirlanaanjani28@gmail.com²
}

\begin{abstract}
This study aims to examine the policy of Islamic banking law in maintaining its existence in the face of the plague that is hitting Indonesia. OJK (Financial Services Authority) has also made a number of policies that are used as an effort to save the economy in Indonesia. One of the regulations is stated in POJK Number 18 / POJK.03 / 2020 concerning "Written Orders for Handling Bank Problems". The legal policy used by Islamic banking is to measure the new OJK regulations as the organizer of an integrated regulatory and supervisory system of all activities in the financial services sector. The method used in this research is descriptive qualitative. The method used in this research is descriptive qualitative. related to the world of banking. The method used in this research is descriptive qualitative. The object of this research is Islamic banking which has more religious wisdom. The results of this study indicate that Islamic banking is making service updates, considering that the transition of the banking world to digital can increase the efficiency of work processes and improve the quality of customer service, by digitizing during the pandemic. The bank has made long-term investments and it is projected that digital services will be one of the main drivers of sustainable banking industry growth in the context of fulfilling POJK Number 18 / POJK.03 / 2020.
\end{abstract}

Keywords: Islamic banking, legal policy, New normal era

\begin{abstract}
Abstrak
Penelitian ini bertujuan untuk menganalisis kebijakan peraturan OJK terhadap perbankan syariah dalam mempertahankan exsistensinya dalam menghadapi wabah yang sedang melanda Indonesia. OJK (Otoritas Jasa Keuangan) juga telah membuat sejumlah kebijakan yang digunakan sebagai upaya pernyelamatan ekonomi di Indonesia. Peraturan tersebut salah satunya tertuang dalam POJK Nomor 18/POJK. 03/2020 tentang "Perintah Tertulis Untuk Penanganan Permasalahan Bank". Kebijakan hukum yang digunakan oleh perbankan syariah adalah menakar peraturan baru OJK)sebagai penyelenggara sistem pengaturan dan pengawan yang terintegrasi terhadap keseluruan kegiatan di sektor jasa keuangan. Metode yang digunakan dalam penelitian ini adalah deskriptif kualitatif. Metode yang digunakan dalam penelitian ini adalah deskriptif kualitatif. yang berhubungan dengan dunia perbankan. Metode yang digunakan dalam penelitian ini adalah deskriptif kualitatif. Objek penelitian ini adalah perbankan syariah yang memiliki kearifan agama yang lebih. Hasil penelitian ini menunjukkan bahwa perbankan syariah melakukan pembaharuan layanan, mengingat peralihan dunia perbankan menjadi digital dapat mengningkatkan efisiensi proses kerja dan meningkatkan kualitas layanan nasabah, dengan melakukan digitalisasi dimasa pandemi. bank sudah melakukan investasi jangka
\end{abstract}


panjang dan diproyeksikan layanan digital menjadi salah satu pendorong utama pertumbuhan industri perbankan secara berkelanjutan dalam rangka pemenuhan POJK Nomor 18/POJK, 03/2020.

Kata Kunci: Perbankan Syariah, Kebijakan hukum, Era new normal

\section{PENDAHULUAN}

Pada awal munculnya perbankan syariah merupakan murni keinginan dari masyarakat Indonesia untuk melakukan transaksi keuangan mereka sesuai dengan prinsip-prinsip sayriah. Dengan semakin berkembangnya perbankan syariah di Indonesia pada tahun 2019, berbanding dengan tahun 2020 yang mengalami penurunan disebabkan oleh Covid-19. Adanya pembatasan sosial di kota-kota besar oleh Pemerintah untuk mengantisipasi tersebarnya Covid-19, hal tersebut menyebabkan banyak sekali perusahaan, toko, pabrik untuk memberlakukan pekerjaan dari rumah sehingga operasional kerja diberhentikan sementara waktu. Dengan adanya keterbatasan ruang gerak dalam kinerja seluruh sektor ekonomi yang ada di Indonesia mengharuskan perusahaan pengelola perbankan syariah untuk berpikir bagaimana kebijakan hukum baru yang tepat dalam mengatasi perlambatan ekonomi di Indonesia. Diterapkannya sistem work from home, yang banyak menyebabkan berkurangnya jam kerja dan menjadikan pengelolaan kinerja kurang maksimal. Seperti yang kita ketahui, Covid-19 memberikan dampak yang cukup signifikan terhadap perkembangan ekonomi di Indonesia dan seluruh dunia. Pada masa pendemi Covid-19 merupakan tantangan dunia dalam sektor bisnis, termasuk industri jasa keuangan perbankan.

Covid-19 sangat memberikan pengaruh yang cukup besar bagi kinerja manusia. Perlambatan masalah ekonomi merupakan salah satu contoh dari banyaknya masalah yang timbul karena pengaruh dari munculnya Covid-19. Perlambatan ekonomi global dan nasional ini tentu menyebabkan turunnya eksistensi perbankan syariah di Indonesia. Kondisi ini mengharuskan mereka mencari inovasi baru agar tetap bisa bertahan menghadapi situasi di masa Pandemi Covid-19. Dengan bertambahnya kasus Covid-19 di Indonesia tersebut membuat perbankan syariah yang selama ini memiliki peran yang kebijakan hukums dalam pembangunan ekonomi rakyat pada aktivitas ekonomi yang produktif, pada situasi Covid-19 perbankan syariah dituntut untuk melakukan usaha, memikirkan kebijakan hukum baru yang digunakan untuk mengatasi segala macam risiko yang terjadi pada masa Covid-19 dengan cepat dan tepat agar tetap bertahan dalam menghadapi situasi tersebut. Sehubungan dengan hal tersebut, maka berbagai kebijakan dikeluarkan OJK (Otoritas Jasa Keuangan) dalam membantu dunia perbankan syariah untuk tetap dapat bertahan ditengah pandemi Covid-19. 
Kebijakan Peraturan OJK Terhadap Perbankan Syariah dalam Menghadapi Wabah Covid-19 di Era New Normal

OJK merangcang kebijakan hukum baru mengingat tidak ada kepastian kapan penyebaran Covid-19 akan berakhir. Kebijakan hukum tersebut tertuang dalam POJK Nomor 18/03/2020 tentang "Perintah Tertulis Untuk Penanganan Permasalahan Bank". Berawal dari permasalahan tersebut, penulis melakukan penelitian ini bertujuan untuk memaparkan bagaimana kebijakan hukum perbankan syariah dalam menghadapi Covid-19 di era new normal. Pembaharuan kebijakan hukum dalam perbankan syariah dapat menciptakan kinerja perbankan yang lebih efektif dan teratur dalam proses pelayanannya terhadap nasabah, pihak perbankan juga harus tetap menerapkan prinsip syariah yaitu prinsip kehati-hatian dalam setiap langkah-langkah yang diambil untuk memutuskan suatu kebijakan dalam perbankan. Selain itu, tulisan ini memaparkan kebijakan OJK dalam menangani permasalahan yang timbul sejak munculnya Covid-19 di Indonesia. Penelitian ini juga dimaksudkan untuk mengetahui bagaimana kebijakan hukum yang dilakukan oleh pihak perbankan syariah terhadap dampak yang timbul dari Covid-19 di era new normal, dan bagaimana mengatasi berbagai permasalahan ekonomi yang dari awal munculnya Covid-19 tersebut menyebabkan penurunan kinerja dalam proses keberlangsungan perekonomian di Indonesia. Hal tersebut peneliti untuk mengakat penelitian dengan judul "Kebijakan Peraturan OJK Terhadap Perbankan Syariah dalam Menghadapi Wabah Covid-19 di Era New Normal."

\section{KAJIAN LITERATUR}

Kebijakan merupakan dasar bertindak mengenai kegiatan tertentu atau suatu rencana tertentu. Kebijakan adalah serangkaian tindakan dasar untuk diikuti dengan tujuan menyelesaikan problem tertentu (Sutrisno Edi, 2007:125). Adapun kebijkan yang dikeluarkan oleh OJK adalah POJK Nomor 18/POJK.03/2020 tentang "Perintah Tertulis Untuk Penanganan Permasalahan Bank" poin b berbunyi "Kewenangan OJK memberikan Perintah Tertulis Kepada Bank untuk:

1. Melakukan penggabungan, peleburan, pengambilalihan, dan/atau integrasi; dan/atau

2. Menerima penggabungan, peleburan, pengambilalihan, dan/atau integrasi.

Otoritas Jasa Keuangan didirikan pada masa pemerintah Susiolo Bambang Yudhoyono. Dasar pembentukannya termuat di dalam undangundang Nomor 21 Tahun 2011 tentang Otoritas Jasa Keuangan. Sebagai lembaga yang mengatur dan mengawasi seluruh kegiatan disektor keuangan. Tujuannya adalah menjadi lembaga yang independen nonpemerintah yang mengatur sektor keuangan secara adil, akuntabel dan 
terbuka tanpa intervensi pihak lain. Selain itu OJK diharapkan mampu meningkatkan daya saing nasional mauun internsional. Pasal 1 undangundang OJK berbunyi:

"OJK adalah Lembaga yang independen dan bebas dari campur tangan pihak lain yang mempunyai fungsi, tugas, dan wewenang pengaturan, pengawasan, pemeriksaan, dan penyidikan sebgaimana yang dimaksud undang-undang ini."

Adapun tugas dan wewenang yang dijalankan oleh perintah Otoritas Jasa Keuangan)yang tertuang dalam BAB III Undang-Undang Nomor 21 tahun 2011 antara lain:

1. Menetapkan peraturan perundang-undagan di sektor jasa keuangan

2. Menetapkan peraturan perintah OJK

3. Membuat dan menerapkan peraturan mengenai pengawasan di sektor keuangan

4. Menetapkan peraturan tentang tata cara penetapan perintah tertulis terhadap jasa keuangan dan pihak tertentu

5. Menetapkan peraturan mengenai tata cara penegenaan sanksi sesuai peraturan perundang-undangan disektor keuangan.

6. Membuat dan memenetapkan kebijakan operasional pengawasan untuk kegiatan jasa keuangan

Uraian diatas memberikan gambaran bahwa perintah OJK sebagai penyelenggara sistem pengaturan dan pengawan yang terintegrasi terhadap keseluruan kegiatan di sektor jasa keuangan melaksanakan kewajibannya dalam upaya penyelamatan dunia perbankan khususnya perbankan syariah. Peraturan tersebut mengingkat pada pendapat Gustav Rabruch (ahli hukum jerman) tentang "peraturan adalah kehendak untuk bersikap adil” (Bernard L. dkk., 2010: 130). Sedangkan asas yang digunakan dalam pembentukan perturan adalah yang memberikan pedoman serta bimbingan untuk semua hal sebagaimana pembentukan yang telah ditentukan (Hamid, 1990).

Purnadi Purbacaraka dan Soerjono Soekanto selanjutnya menguraikan beberapa asas dalam perundangan-undangan Indonesia, yakni: Undangundang yang bersifat khusus mengesampingkan yang lebih umum. Undang-undang yang berlaku belakangan membatalkan undang-undang yang berlaku terdahulu (Yuliandri, 2009: 117).

\section{METODE PENELITIAN}

Metode penelitian ini adalah kualitatif deskriptif. Penelitian ini mempelajari masalah-masalah, tata cara, situasi tertentu, segala sesuatu yang berhubungan, kegiatan, sikap, pandangan, proses serta pengaruhpengaruh dari suatu peristiwa yang tengah terjadi di dalam masyarakat (Moh. Nizar, 2013: 55). Penelitian ini bersifat descriptive research. 
Kebijakan Peraturan OJK Terhadap Perbankan Syariah dalam Menghadapi Wabah Covid-19 di Era New Normal

Descriptive research adalah pencarian fakta dengan interpretasi yang tepat. Penelitian ini mempelajari masalah-masalah, tata cara, situasi tertentu, segala sesuatu yang berhubungan, kegiatan, sikap, pandangan, proses serta pengaruh-pengaruh dari suatu peristiwa yang tengah terjadi di dalam masyarakat. Sekilas descriptive research mirip dengan pekerjaan seorang wartawan yaitu mengamati dan kemudian menceritakan kedalam tulisan di media masa. Namun penelitian ini merupakan pengamatan yang bersifat ilmiah yang dilakukan secara hati-hati, cermat, dan akurat (Moh. Nizar, 2013: 55).

\section{HASIL PEMBAHASAN}

Eksistensi perbankan syariah di Indonesia sangat berpengaruh terhadap pembangunan ekonomi dengan berprinsip syariah, yang memberikan solusi dalam menghadapi pemberdayaan usaha kecil dan menengah. Hal tersebut menunjukkan bahwa peranan bank syariah sangat berpengaruh bagi masyarakt. Masa Pandemi Covid-19 seperti saat ini, pada sektor ekonomi perbankan syariah cukup banyak tantangan, dengan ketidakpastian kapan masa Pandemi Covid-19 akan berakhir menjadi acuan untuk perbankan syariah untuk tetap waspada dan segera menyusun kebijakan hukum baru untuk menyiapkan tatanan kehidupan baru atau sering disebut new normal, mengingat kondisi ekonomi dan stabilitas keuangan berubah cepat di masa Pandemi Covid-19 sedang rentan. Dikutip dalam situs ekonomi.bisnis.com, adapun pengaruh penurunan pendapatan pada sektor lapangan usaha dapat dilihat sebagai berikut:

\begin{tabular}{|cc|}
\hline akomodasi dan makanan & $\bullet 92,47 \%$ \\
\hline transporatasi dan pergudangan & $\bullet 90,34 \%$ \\
\hline konstrusksi & $\bullet 87,94 \%$ \\
\hline Industri Pengolahan & $\bullet 85,98 \%$ \\
\hline Perdangangan & $\bullet 84,60 \%$ \\
\hline
\end{tabular}

Pandemi Covid-19 menyerang berbagai sektor bisnis, tidak terkecuali pada perbankan syariah. Sebagai lembaga keuangan yang berperan sebagai pensejahtera rakyat banyak dan juga lembaga keuangan yang memiliki peran besar dalam ekonomi negara, bank syariah tidak akan 
bisa berjalan sendiri tanpa adanya peran masyarakat sebagai konsumen atau nasabah dalam bank syariah tersebut sehingga kemajuan perbankan syariah bergantung kepada aktivitas masyarakat, sehingga ketika masyarakat dipaksa tinggal di rumah karena kebijakan dari Pemerintah, maka bank juga akan mengalami penurunan pendapatan. Munculnya peningkatan risiko tersebut tidak luput dari adanya pembatasan aktivitas sosial dan ekonomi untuk menekan penyebaran Covid-19 yang terus meningkat setiap harinya. Resiko buruk yang dihadapi adalah menurunnya laju pendapatan operasional (BOPD) hingga akhir 2019. Hal tersebut dapat dilihat berdasarkan laporan perkembangan keuangan syariah (www.ojk.go.id, 2021).

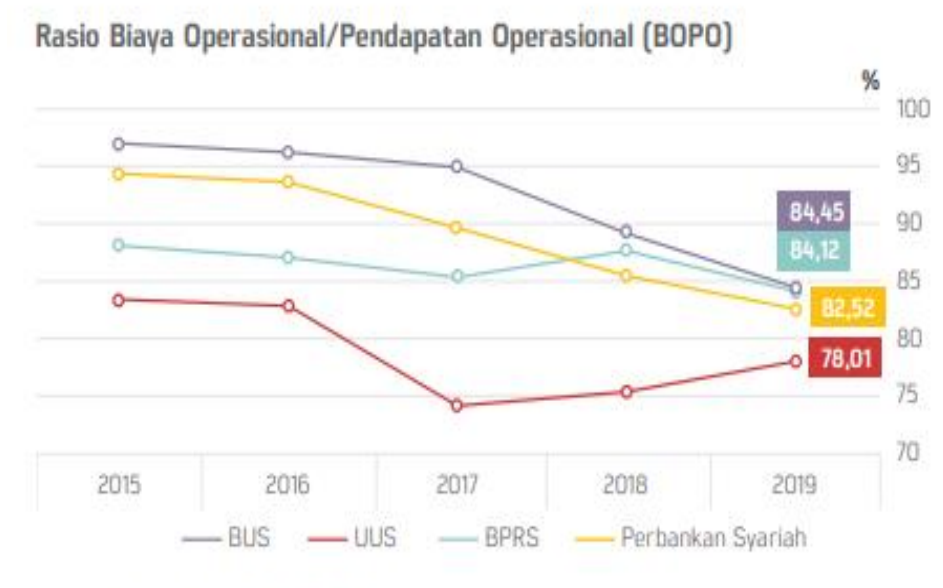

Sumber. Otoritas Jasa Keuangan, 2019

Pembatasan aktivitas sosial dan ekonomi menyebabkan terbatasnya kegiatan, risiko tersebut dialami oleh perbankan syariah dan bank umum lainnya yang harus tetap diwaspadai. Secara teknis jenis kegiatan masyarakat yang diatur dalam Peraturan Menteri Kesehatan (PMK) No.9 Tahun 2020 tentang Pedoman PSBB sebagai Percepatan Penanganan COVID-19 antara lain meliputi meliburkan sekolah dan tempat kerja, pembatasan kegiatan keagamaan, pembatasan kegiatan di tempat umum, pembatasan kegiatan sosial budaya, pembatasan moda transportasi, dan pembatasan kegiatan lainnya khusus terkait aspek pertahanan keamanan.

Pemerintah juga menegaskan perbedaan PSBB dengan karantina wilayah dimana masyarakat tidak diperkenankan untuk beraktivitas di luar rumah. PSBB diterapkan pertama kali di Provinsi Daerah Khusus Ibukota (DKI) Jakarta pada tanggal 10 April 2020 dimana Jakarta merupakan episentrum wabah Covid-19 di Indonesia. Jakarta sendiri bersama beberapa kabupaten dan kota di Indonesia sudah melakukan kebijakan darurat wabah Covid-19 secara lokal dengan memberlakukan libur sekolah untuk sekolah negeri dan himbauan untuk sekolah swasta, 
Kebijakan Peraturan OJK Terhadap Perbankan Syariah dalam Menghadapi Wabah Covid-19 di Era New Normal

pembatasan transportasi umum milik pemda, menutup tempat wisata milik pemda, menghimbau agar kantor-kantor baik pemerintah pusat maupun swasta agar melakukan pekerjaan di rumah (work from home) dan beberapa kebijakan lain yang masih merupakan lingkup kewenangan pemerintah daerah.

Lembaga konsultan McKinsey pada akhir Maret 2020 menerbitkan laporan mengenai dampak Covid-19 pada dunia bisnis. Berikut adalah beberapa hal penting yang dijelaskan McKinsey dalam laporan mereka antara lain:

1. Covid-19 adalah bencana besar yang belum pernah terjadi sebelumnya. Berbagai laporan menyebutkan bahwa bencana wabah terbesar sebelumnya terjadi satu abad yang lalu, sekitar tahun 19181920 dimana wabah Spanish influenza menyerang dunia dengan korban meninggal dunia diperkirakan antara 50 - 100 ribu jiwa.

2. tentang model penanganan, China adalah paling banyak dirujuk mengingat Covid-19 ini muncul pertama kali di wilayah China dimana pemerintahnya memberlakukan kebijakan karantina wilayah secara ketat di hampir semua kota yang terjangkit, terutama di wilayah Wuhan. Model berikutnya adalah Korea Selatan yang memilih karantina wilayah secara parsial namun dengan dibarengi tes massal yang sangat agresif, disertai pelacakan kontak, isolasi dan karantina terhadap mereka yang positif Covid-19 dengan pemantauan yang sangat ketat.

3. tentang bagaimana menyusun kebijakan hukum yang tepat dalam dua hal yang sangat bertentangan, yaitu menyelamatkan banyak nyawa dengan karantina yang ketat, tetapi di sisi lain harus tetap memprioritaskan untuk menyelamatkan perekonomian dari guncangan dampak Covid-19.

4. kapitalisasi pasar pada kuartal pertama ini adalah yang terburuk dalam sejarah dan masih akan terpuruk dalam jangka waktu yang belum dapat diprediksi. Beberapa sektor bisnis, terutama minyak dan gas, transportasi udara, perawatan kesehatan, dan keuangan akan mengalami pertumbuhan negatif yang cukup lama, dan kemungkinan baru akan pulih paling cepat setelah tahun 2021 atau 2 tahun setelah pandemi Covid-19 ini.

Lebih khusus tentang dampak pada sektor ketenagakerjaan, Organisasi Ketenagakerjaan Internasional (ILO) menerbitkan ILO Monitor 2nd edition pada April 2020 dimana laporan ini menguraikan beberapa hal penting menyangkut dampak Covid-19 terhadap kondisi ketenagakerjaan seluruh dunia, antara lain: 
1. Kebijakan karantina wilayah di berbagai negara berdampak pada 81 persen dari total pekerja di seluruh dunia.

2. Kontraksi ekonomi secara langsung mempengaruhi penyempitan lapangan kerja. Perhitungan ILO per 1 April 2020 menunjukkan penurunan jam kerja sebesar 6,7 persen pada kuartal kedua 2020 atau setara dengan hilangnya 195 juta pekerjaan penuh waktu.

3. Perhitungan total kehilangan pekerjaan pada tahun 2020 tergantung pada perkembangan pandemi ini, bagaimana pemerintah masingmasing negara mengantisipasinya, serta penemuan obat dan vaksin sehingga diketahui kepastian berakhirnya pandemi. ILO akan terus memantau dan diperkirakan bahwa jumlah orang yang menganggur akan semakin bertambah.

4. Beberapa sektor tertentu yang menjadi penyumbang mayoritas hilangnya pekerjaan dan penurunan jam kerja. Perkiraan ILO menunjukkan bahwa sekitar 1,25 miliar pekerja atau 38 persen dari total pekerja terancam akan diberhentikan yang meliputi sektor perdagangan ritel, akomodasi dan makanan, dan manufaktur.

5. Khususnya di negara-negara berpenghasilan menengah ke bawah, sektor-sektor yang terkena dampak besar umumnya memiliki proporsi pekerja informal yang tinggi dimana para pekerjanya tidak memiliki jaminan sosial, atau punya tetapi dalam keadaan minimal. Para pekerja ini kini berada dalam kondisi paling rentan di antara kelompok pekerja lainnya.

6. Pekerja di sektor kesehatan sangat rentan terhadap paparan risiko kesehatan dan risiko ekonomi. Walaupun belum ada angka seluruh dunia yang resmi, berbagai laporan menunjukkan besarnya korban pada para tenaga kesehatan terutama yang berhubungan langsung dengan pandemi Covid-19.

7. Respon kebijakan harus diarahkan ke bantuan segera untuk pekerja dan sektor-sektor usaha tertentu untuk melindungi mata pencaharian. Terutama di negaranegara berkembang dan di sektorsektor tertentu dengan dampak yang signifikan. Dengan demikian, ketika pandemi berlalu, negara dapat memulihkan ekonomi lebih cepat.

Indonesia diprediksi pada tahun 2020 ini akan didominasi oleh prospek ekonomi yang memudar, dimana pelambatan ini sudah diprediksi sebelum pecahnya Covid-19. Covid-19 membuat perekonomian Indonesia lebih dalam terpuruk. Tingkat kemiskinan diperkirakan akan menurun, tetapi proporsi orang yang rentan (tanpa jaminan ekonomi) akan sangat meningkat. Pernyataan tersebut dapat dilihat dari Info Grafis Bulan Juni 2020 yang mengulas tentang Overvier Makroekonomi secara global dan 
Kebijakan Peraturan OJK Terhadap Perbankan Syariah dalam Menghadapi Wabah Covid-19 di Era New Normal

domestik. Adapun grafik laporannya dapat dilihat sebagai berikut (www.ojk.go.id, 2021):

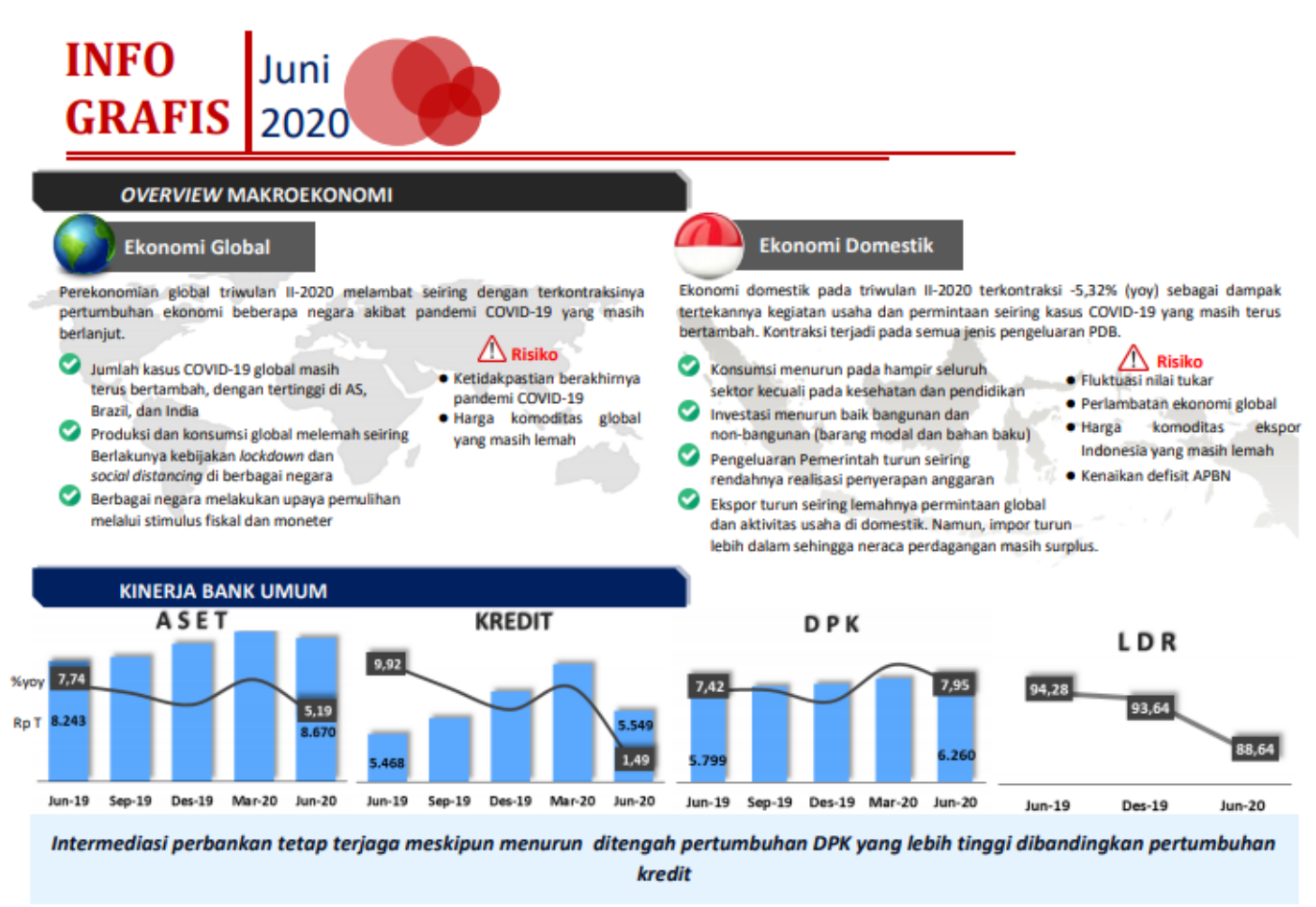

Perbankan syariah dituntut untuk tetap melayani nasabah dari rumah, dengan begitu bank syariah harus menyesuaian pola bisnis akibat dari Covid-19. Otoritas Jasa Keuangan (OJK) menyebutkan bahwa pelayanan perbankan digital akan diterakan baik untuk perbankan syariah maupun bank umum. Kegiatan pelayanan digital ini menggunakan media electronik atau digital milik bank. Digitalisasi pelayanan perbankan memungkinkan bagi nasabah dan calon nasabah untuk memperoleh pelayanan secara mandiri tanpa harus datang langsung ke bank. Dengan begitu, pihak perbankan dan nasabah akan tetap mematuhi peraturan Pemerintah karena pembatasan aktivitas sosial untuk menekan penyebaran Covid-19 tersebut (Muhyiddin, 2020:244).

Setiap industri harus siap bergerak menghadapi perubahanperubahan dinamis. Industri perbankan syariah juga mau tidak mau harus menyesuaikan diri dengan perkembangan teknologi yang ada, digitalisasi mengharuskan bank syariah melakukan pembaharuan layanan, mengingat peralihan dunia perbankan menjadi digital dapat mengningkatkan efisiensi proses kerja dan meningkatkan kualitas layanan nasabah, dengan melakukan digitalisasi, bank sudah melakukan investasi jangka panjang dan diproyeksikan layanan digital menjadi salah satu pendorong utama 
pertumbuhan industri perbankan secara berkelanjutan (Hani Tahliani, 2020:105). Digitalisasi ini merupakan salah satu kebijakan hukum yang dapat digunakan pada perbankan syariah untuk mengatasi permasalahan ekonomi di Indonesia. Manfaat digitalisasi bagi perbankan merupakan upaya menurunkan biaya operasional, digitalisasi pihak bank dapat dengan mudah menjangkau pasar yang lebih luas dan salah satu tujuan adanya digitalisasi tersebut juga untuk mencapai kepuasan pelanggan dalam menggunkan produk-produk bank.

Jasa perbankan yang ditawarkan kepada pelangan personal bank untuk melakukan transaksi banking rutin melalui internet disebut dengan Internet Banking. Internet Banking ini merupakan suatu sistem yang memungkinkan nasabah bank untuk mengakses rekening dan informasi umum produk dan jasa suatu bank melalui Personal Computer (PC) atau alat pandai lainnya. Umumnya transaksi ini meliputi pengecekan rekening, mengamati daftar transaksi yang menggunakan rekening, dan mentransfer dana dari satu rekening online ke rekening lainnya. Internet Banking memungkinkan pengguna untuk melakukan dial dan menggunakan software internet service provider bank. Tipe banking ini memungkinkan pelanggan untuk mengakses rekening bank di lokasi yang tersedia akses internet.

Biaya transaksi bank melalui internet adalah yang termurah. Ditinjau dari perspektif konsumen, Internet Banking menyediakan pendekatan yang nyaman dan efektif dalam mengatur alat-alat pembayaran seseorang yang dapat diakses 24 jam setiap harinya. Khusus untuk perusahaan, paket cash management yang canggih menawarkan mereka informasi terbaru tiap menitnya, mengijinkan keputusan manajemen dana setiap saat Berdasarkan Basel Committee on Banking Supervision, terdapat tiga tingkatan Internet Banking, yaitu:

1. Basic information website,

Pada tingkat ini hanya memberikan informasi tentang produk/jasa yang ditawarkan kepada nasabah bank dan publik umum;

2. Simple transactional web,

Pada tingkat ini nasabah hanya diijinkan melakukan transaksi bank biasa seperti menanyakan rekening, memasukkan instruksi ke bank, tapi tidak mengijinkan adanya transfer rekening sama sekali;

3. Advanced transactional website,

Pada tingkat ini mengijinkan nasabah bank secara penuh untuk transfer dana dari/ke rekening mereka, membayar tagihan dan melakukan transaksi online lainnya. Aplikasi teknologi informasi dalam Internet Banking akan meningkatkan efisiensi, efektifitas, dan produktifitas sekaligus meningkatkan pendapatan melalui sistem penjualan yang jauh lebih efektif daripada bank konvensional. Tanpa adanya aplikasi 
Kebijakan Peraturan OJK Terhadap Perbankan Syariah dalam Menghadapi Wabah Covid-19 di Era New Normal

teknologi informasi dalam Internet Banking, maka Internet Banking tidak akan jalan dan dimanfaatkan oleh industri perbankan.

Secara umum, dalam penyediaan layanan Internet Banking, bank memberikan informasi mengenai produk dan jasanya via portal di internet, memberikan akses kepada para nasabah untuk bertransaksi dan mengupdate data pribadinya. Persayaratan bisnis dari Internet Banking antara lain aplikasi mudah digunakan, layanan dapat dijangkau dari mana saja, murah, aman, dan dapat diandalkan (reliable).

Internet Banking memberikan keuntungan antara lain: Business expansion, dahulu sebuah bank harus memiliki sebuah kantor cabang untuk beroperasi di tempat tertentu. Kemudian hal ini dipermudah dengan hanya meletakkan mesin ATM sehingga dia dapat hadir di tempat tersebut. Kemudian ada phone banking yang mulai menghilangkan batas fisik dimana nasabah dapat menggunakan telepon untuk melakukan aktivitas perbankannya. Sekarang ada Internet Banking yang lebih mempermudah lagi karena menghilangkan batas ruang dan waktu. Customer loyality, khususnya nasabah yang sering bergerak (mobile), akan merasa lebih nyaman untuk melakukan aktivitas perbankannya tanpa harus membuka account di bank yang berbeda-beda di berbagai tempat. Dia dapat menggunakan satu bank saja (Riftiani, Lestari, \& Hana, 2020).

Revenue and cost improvement, biaya untuk memberikan layanan perbankan melalui Internet Banking dapat lebih murah daripada membuka kantor cabang atau membuat mesin ATM. Competitive advantage,bank yang memiliki Internet Banking akan memiliki keuntungan dibandingkan dengan bank yang tidak memiliki Internet Banking. Dalam waktu dekat, orang tidak ingin membuka account di bank yang tidak memiliki fasilitas Internet Banking. New business mode, Internet Banking memungkinan adanya bisnis model yang baru seperti jual belo online. Karena pada masa Pandemi Covid-19 masyarakat dihimbau agar tetap di rumah saja, sedangkan pada dasarnya dalam kehidupan sehari-hari masyarakat tidak pernah lepas dari yang namanya transaksi jual beli. Dengan adanya produk Internet Banking pada bank syariah, menjadikan perbankan syariah sebagai perbankan yang dapat disamakan dengan perbankan umu atau konvensional.

Layanan perbankan baru dapat diluncurkan melalui web dengan cepat. Aplikasi teknologi informasi dalam Internet Banking secara garis besar dapat dibagi menjadi dua bagian: front-end (yang berhubungan dengan nasabah) dan back-end (yang berhubungan dengan bank). Kedua bagian ini biasanya dipisahkan dengan firewall (bisa sebuah firewall atau beberapa firewall jika dibutuhkan keandalan dan kinerja yang sangat tinggi) (Yusnaini, 2010:5). 
Agar dapat bertahan dan bahkan keluar sebagai pemenang setelah krisis Covid-19 ini berlalu, pelaku ekonomi dan bisnis disarankan untuk melakukan tiga hal antara lain: pertama, kebijakan hukumc team alignment, pada era krisis sangatlah mudah bagi pemimpin perusahaan untuk panik dan cenderung melupakan bahwa ada banyak orang yang sebenarnya memiliki kapasitas untuk membantu perusahaan bertahan. Kedua, para pelaku bisnis disarankan untuk memulai mengembangkan bussiness continuity plan yaitu perencanaan kelangsungan bisnis yang merupakan kebijakan hukum untuk mengurangi dampak bencana terhadap aktivitas bisnis. Ketiga, pelaku bisnis sebaiknya membentuk tim khusus untuk mengeksekusi semua hal yang direncanakan secara cepat dan tepat karena perusahaan perlu mengeksekusi melalui berbagai langkah yang benar dan teratur (Yenti, 2020: 53). Langkah Kebijakan hukum tersebut dapat digunakan dalam perbankan syariah dengan perencanaan yang tepat dan sekaligus dapat digunakan dalam jangka waktu yang panjang, karena tidak adanya kepastian berakhirnya Covid-19 tersebut.

Kebijakan hukum lain yang dapat dijadikan untuk menyelesaikan permasalahan ekonomi, terlebih lagi pada sektor perbankan syariah, pihak bank syariah harus melakukan pendampingan kepada debiturnya terutama pada pelaku UMKM. Mereka harus diberikan pendampingan dan pengarahan agar tetap bisa menjalankan usahanya dengan begitu mereka masih bisa memiliki kemampuan untuk membayar kewajibannya terhadap bank itu sendiri. Dengan kata lain, pada kemampuan mereka membayar kewajibannya terhadap bank tidak sama pada saat kondisi sebelum munculnya Covid-19 yang mungkin akan berkurang pendapatan daam menjalankan usahanya. Hal tersebut harus dipikirkan kembali kebijakan hukum untuk membuat kebijakan baru, semisal dengan cara pengurangan nominal untuk membayar kewajibannya debitur kepada pihak perbankan, tetapi pembayaran kewajiban tersebut harus dilakukan secara bertahap dan teratur dalam setiap bulannya agar pihak perbankan juga tetap bisa menjalankan kegiatannya dan dapat berusaha menstabilkan masalah pembiayaan.

Respons Pemerintah sebagai upaya mengatasi krisis keuangan pada kondisi Pandemi dilakukan dengan mengeluarkan regulasi atas pengaturan keuangan negara. Ada dua regulasi keuangan negara yang dikeluarkan oleh negara untuk mengatur pembiayaan keuangan bagi masyarakat. Dua aturan tersebut yaitu Peraturan Pemerintah Pengganti Undang-Undang Nomor 1 Tahun 2020 dan POJK Nomor 11/POJK.03/2020 tentang Stimulus Perekonomian Nasional Sebagai Kebijakan Countercyclical dampak Penyebaran Coronavirus Disease Disease 2019 tanggal 16 Maret 2020. Sesuai peraturan OJK tersebut diatas, debitur perbankan diberikan penundaan sampai dengan 1 (satu) tahun dan 
Kebijakan Peraturan OJK Terhadap Perbankan Syariah dalam Menghadapi Wabah Covid-19 di Era New Normal

penurunan bunga. Penundaan yang dimaksud yaitu penangguhan angsuran pembiayaan. Untuk mekanismenya, setiap utang atau pembiayaan direstrukturisasi oleh pihak bank atau perusahaan pembiayaan dapat ditetapkan lancar apabila diberikan kepada debitur yang teridentifikasi terkena dampak penyebaran Covid-19.

Restrukturisasi pembiayaan adalah bantuan pelunasan pinjaman. Restrukturisasi bukanlah penghapusan, tetapi memberikan kelonggaran untuk melunasi pembayaran utang (Setiyaningsih, Haryanti, \& Hana, 2020). Pinjaman masih harus dibayar tetapi diberikan keringanan berdasarkan penilaian dan kesepakatan dengan Bank. Relaksasi dari pengaturan ini berlaku untuk debitur Non-UKM dan UKM, dengan masa berlaku hingga satu tahun dari 13 Maret 2020 hingga 31 Maret 2021. Pelaksanaannya tergantung pada kebijaksanaan masing-masing bank. POJK No. 18/POJK.03/2020 mengambil langkah-langkah untuk menjaga stabilitas sistem keuangan, terutama di sektor perbankan, ancaman pelemahan ekonomi akibat pandemi COVID-19. OJK memberikan perintah kepada Bank untuk yang Pertama, melakukan merger, konsolidasi, pengambilalihan, dan atau integrasi. Kedua, menerima merger, konsolidasi, akuisisi, atau integrasi. Kebijakan selanjutnya tentang industri perbankan yang dikeluarkan oleh otoritas selama PSBB (SP 26/DHMS OJK/IV/2020).

Menurut Siaran Pers dalam Operasi Industri Jasa Keuangan Selama Periode Implementasi PSBB di Berbagai Daerah. Isinya bahwa OJK meminta lembaga jasa keuangan untuk bekerja dengan jumlah minimum karyawan sesuai dengan protokol kesehatan di tempat kerja. Lembaga layanan keuangan harus mematuhi prosedur PSBB untuk diimplementasikan, seperti physical distancing, mengurangi layanan dengan tatap muka dan sebagai gantinya perbankan dapat memaksimalkan penggunaan teknologi dan selalu menjaga kesehatan. Sedangkan untuk peraturan pekerjaan dari rumah, diserahkan kepada masing-masing Lembaga Jasa Keuangan.

Kebijakan Stimulus Perekonomian Nasional yaitu No.11/POJK.03/2020 Bank juga memberikan melonggarkan fasilitas pembiayaan kepada nasabah yang tedampak pandemi Covid-19 dalam bentuk penundaan pembayaran dan atau penurunan margin atau bagi hasil untuk jangka waktu tertentu dan persyaratannya disesuaikan dengan sektor ekonomi, kriteria, dan kondisi nasabah dengan tetap mengacu pada ketentuan OJK untuk nasabah terutama UKM yang secara tidak langsung mempengaruhi perekonomian nasional (Mardhiyaturrositaningsih \& Muhammad Syarqim Mahfudz, 2020: 4). Hal tersebut yang mejadi stimulus 
kuat OJK dalam mengeluarkan berbagai peraturan dalam upayanya menyelamatkan sektor keuangan perbankan.

Aturan dari OJK tersebut diatas juga diperkuat dalam Peraturan Pemerintah Pengganti Undang-Undang Nomor 1 Tahun 2020 tentang Kebijakan Keuangan Negara dan Stabilitas Sistem Keuangan untuk Penanganan Pandemi Covid-19) dan/atau dalam Rangka Menghadapi Ancaman yang Membahayakan Perekonomian Nasional dan/atau Stabilitas Sistem Keuangan. Dalam Peraturan Pemerintah tersebut sejumlah kebijakan diambil seperti mengalokasikan tambahan belanja dan pembiayaan APBN Tahun 2020 untuk penanganan Covid-19. Untuk keperluan tersebut, pemerintah mengucurkan anggaran sebesar Rp 450,1 triliun yang selanjutnya akan diperuntukkan kepada sejumlah bidang penanganan mulai dari sisi kesehatan hingga dampak ekonomi yang ditimbulkannya. Regulasi yang telah disebutkan diatas, secara umum masyarakat merespons kebijakan tersebut dengan positif dan tentunya memberikan angin segar, bukan hanya membantu bagi masyarakat terdampak pandemi Covid-19 bahkan memberikan angin segar bagi Industri Perbankan (Hani Tahliani, 2020: 108).

Regulasi dari dua payung hukum tersebut belum terlihat dampaknya untuk masyarakat. Masih banyak debitur yang mengalami penurunan penghasilan dampak Pandemi belum merasakan kemudahan dari berlakunya dua payung hukum tersebut. Kebijakan hukum yang diambil oleh pemerintah belum dapat dinikmati secara cepat dan menyeluruh oleh debitur. Jika kondisi tersebut masih berlangsung terus dengan jangka waktu lama, maka akan memberikan pengaruh kuat terhadap penurunan pertumbuhan ekonomi Indonesia (Muhammad Ubaidillah 2020:3). Kebijakan yang telah dikeluarkan oleh Pemerintah Indonesia melalui Undang-Undang Nomor 2 Tahun 2020 POJK Nomor 11/POJK.O3/2020 yang memberikan kelonggaran terhadap debitur yang mengalami kesulitan akibat Covid-19, misalnya pada sektor usaha kecil dan menengah mendapatkan restrukturisasi terhadap kredit atau pembiayaan yang terkena dampak dari Covid-19 dan diharapkan dari kebijakan tersebut, para nasabah yang mempunyai kredit pembiayaan pada bank syariah dapat mengelola usahanya dengan baik, hal ini merupakan upaya untuk mengembalikan kestabilan masalah ekonomi di Indonesia.

Untuk tetap berkembang di tengah pandemi covid-19 agar industri perbankan syariah tetap berada dalam aturan-aturan syariah dan tetap menjalankan fungsi bank syariah sesuai kaidah yang berlaku. Selain itu, bank syariah juga diharuskan menjaga kesesuaian prinsip-prinsip syariah dalam operasionalnya serta menjaga reputasi sebagai Bank Syariah, termasuk manajemen syariah yang harus baik, agar tidak ada anggapan 
Kebijakan Peraturan OJK Terhadap Perbankan Syariah dalam Menghadapi Wabah Covid-19 di Era New Normal

buruk terhadap pengelolaan bank syariah karena hal tersebut akan sangat berpengaruh terhadap perkembangan dan popularitas perbankan syariah.

Keseluruhan kebijakan hukum perbankan syariah anatara lain melihat risiko, yang dilakukan oleh bank pasti akan lakukan restrukturisasi. Kemudian dipilah dari keseluruhan debitur mana yang layak direstrukturisasi dan mana yang belum layak. Perbankan syariah tetap harus tumbuh. Oleh karena itu mereka akan fokus pada industri yang masih bisa memiliki prospek baik di tengah pandemi. Perbankan syariah akan fokus mengembangan digital banking dan online banking. Kondisi pandemi Corona saat ini menguji layanan digital dan online banking perbankan syariah apakah benar dimanfaatkan oleh nasabahnya. perbankan syariah harus melakukan pendampingan kepada para debiturnya terutama UMKM. Mereka harus diberikan pendampingan untuk mempertahankan usahanya. Dengan begitu mereka masih bisa memiliki kemampuan untuk membayar kewajibannya. Perbankan syariah mau tidak mau harus melakukan digital marketing. Kondisi pandemi memaksa semua pertemuan dilakukan secara virtual. Hal itu harus dimanfaatkan sebagai ajang untuk berjualan.

\section{KESIMPULAN}

Munculnya Covid-19 pada tahun 2020 ini, menyebabkan timbulnya permasalahan diseluruh sektor, tidak terkecuali pada perbankan syariah. Covid-19 juga mempengaruhi permasalahan ekonomi secara signifikan yang menyebabkan penurunan pendapatan mulai dari usaha kecil, menengah sampai dengan perusahaan juga mengalami penurunan pendapatan dan kinerja pengelolaan usaha menjadi terhambat dengan adanya Covid-19. Dengan adanya masalah tersebut, para pihak perbankan syariah dan usaha lainnya, dituntut untuk membuat kebijakan hukum baru untuk bisa bertahan dalam kondisi krisis ekonomi yang dianggap paling parah secara global.

Mengenai permasalahan tersebut Pemerintah membuat sebuah kebijakan agar tidak terjadi penyebaran Covid-19 semakin bertambah, yaitu dengan adanya pembatasan aktivitas sosial berskala besar yang diterapkan pada kota-kota besar. Adanya pembatasan aktivitas sosial tersebut, menyebabkan kinerja perbankan syariah semakin terbatas dan semakin dituntut untuk segera membuat kebijakan hukum yang tepat untuk menciptakan kenyamanan dan kepercayaan para nasabah dalam menggunakan bank syariah.

POJK Nomor 11/POJK.03/2020 tentang Stimulus Perekonomian Nasional Sebagai Kebijakan Countercyclical Dampak Penyebaran Covid2019 tanggal 16 Maret 2020. Sesuai peraturan OJK tersebut diatas, debitur 
perbankan diberikan penundaan sampai dengan 1 (satu) tahun dan penurunan bunga. Penundaan yang dimaksud yaitu penangguhan angsuran pembiayaan. Untuk mekanismenya, setiap utang atau pembiayaan direstrukturisasi oleh pihak bank atau perusahaan pembiayaan dapat ditetapkan lancar apabila diberikan kepada debitur yang teridentifikasi terkena dampak penyebaran Covid-19.

Restrukturisasi pembiayaan adalah bantuan pelunasan pinjaman. Restrukturisasi bukanlah penghapusan, tetapi memberikan kelonggaran untuk melunasi pembayaran utang. Pinjaman masih harus dibayar tetapi diberikan keringanan berdasarkan penilaian dan kesepakatan dengan Bank. Kebijakan Stimulus Perekonomian Nasional yaitu No.11/POJK.03/2020 Bank juga memberikan melonggarkan fasilitas pembiayaan kepada nasabah yang tedampak pandemi Covid-19 dalam bentuk penundaan pembayaran dan atau penurunan margin atau bagi hasil untuk jangka waktu tertentu dan persyaratannya disesuaikan dengan sektor ekonomi, kriteria, dan kondisi nasabah dengan tetap mengacu pada ketentuan OJK untuk nasabah terutama UKM. Kebijakan hukum lain yang dapat dijadikan untuk menyelesaikan permasalahan ekonomi, terlebih lagi pada sektor perbankan syariah, pihak bank syariah harus melakukan pendampingan kepada debiturnya terutama pada pelaku UMKM. Mereka harus diberikan pendampingan dan pengarahan agar tetap bisa menjalankan usahanya dengan begitu mereka masih bisa memiliki kemampuan untuk membayar kewajibannya terhadap bank itu sendiri.

Selain itu, untuk tetap berkembang di tengah pandemi Covid-19 industri perbankan syariah tetap berada dalam aturan-aturan syariah dan tetap menjalankan fungsi bank syariah sesuai kaidah yang berlaku. Perbankan syariah juga diharuskan menjaga kesesuaian prinsip-prinsip syariah dalam operasionalnya serta menjaga reputasi sebagai Bank Syariah, termasuk manajemen syariah yang harus baik, agar tidak ada anggapan buruk terhadap pengelolaan bank syariah karena hal tersebut akan sangat berpengaruh terhadap perkembangan dan popularitas perbankan syariah.

\section{DAFTAR PUSTAKA}

Attamini, Hamis S. (1990). Peranan Keputusan Presiden Indonesia dalam Penylnggaraan Pemerintah Negara, Suatu Studi Analisis Mengenai Keputusan Presiden yang Berfungsi Pengaturan dalam Kurun Waktu. Program Pasca Sarjana Universitas Jakarta.

Bernard L. Dkk. (2010).Teori Hukum, Strategi Tertib Manusia Lintas Ruang dan Generasi. Yogyakarta: Genta Publishing.

Edi, Sutrisno. (2007). Menejemen Sumber Daya Manusia. Jakarta: Kencana, Mardhiyaturrositaningsih \& Muhammad Syarqim Mahfudz. (2020).

Dampak Pandemi Covid-19 Terhadap Manajemen Industri 
Kebijakan Peraturan OJK Terhadap Perbankan Syariah dalam Menghadapi Wabah Covid-19 di Era New Normal

Perbankan Syariah: Analisis Komparatif. Jurnal Ekonomi dan Manajemen, Vol 2 (1).

Moh. Nizar, (2013). Metodologi Penelitian. Bogor: Ghalia Indonesia.

Morisan. (2014). Metode Penelitian Survey. Jakarta: Prenadamedia Group.

Muhyiddin. (2020). Covid-19, New Normal dan Perencanaan Pembangunan di Indonesia. The Indonesian Journal of Development Planning, Vol 4 (2).

POJK Nomor 18/POJK (OTORITAS JASA KEUANGAN).03/2020 tentang "Perintah Tertulis Untuk Penanganan Permasalahan Bank"

Riftiani, R. I., Lestari, D. P., \& Hana, K. F. (2020). Implementation of Sharia Management in Islamic Mutual Fund Products Rizki Ikha Riftiani. Journal of Finance and Islamic Banking, 3(1), 77-94. https://doi.org/10.22515/jfib.v3i1.2626

Setiyaningsih, A., Haryanti, I., \& Hana, K. F. (2020). Ada Apa Dengan Kinerja di Bank Panin Dubai Syariah? BanKu: Jurnal Perbankan Dan Keuangan, 1(Agustus), 60-74.

Sumarni, Yenti. (2020). Pandemi Covid-19: Tantangan Ekonomi dan Bisnis. Al-intaj, Vol 6(2).

Tahliani, Hani. (2020). Tantangan Perbankan Syariah dalam Menghadapi Pandemi Covid-19. Jurnal Madani Syariah, Vol 3(2).

Ubaidillah, Muhammad. (2020). Tinjauan Atas Implementasi Perpanjangan Masa Angsuran Untuk Pembiayaan Di Bank Syariah Pada Situasi Pandemi Covid-19, Jurnal Pemikiran dan Pengembangan Perbankan Syariah, Vol 6(1).

UU Nomor 21 Tahun 2011 tentang perintah OJK (Otoritas Jasa Keuangan)

Yuliandri. (2009). Asas-Asas Pembentukan Peraturan Perundang-undangan yang Baik, Gagasan Pembentukan Undang-Undang Berkelanjutan, Jakarta: Raja Grafindo Persada.

Yusnaini. (2010). Pengaruh Kualitas Pelayanan Internet Banking Terhadap Kepuasan Dan Loyalitas Konsumen Pada Bank Swasta. Jurnal Dinamika Akuntansi, Vol 2(1).

https:/ / ekonomi.bisnis.com/read/20200915/12/1291857/survei-bpscovid-19-tekan-semua-sektor-usaha, akses tanggal 5 Maret 2021.

https://www.ojk.go.id/id/berita-dan-kegiatan/siaranpers/Pages/Siaran-Pers-OJK (OTORITAS JASA KEUANGAN)Keluarkan-Peraturan-Terkait-Penanganan-Dampak-Covid-19.aspx, akses tanggal 5 Maret 2021.

https:/ / www.ojk.go.id/id/kanal/perbankan/data-dan-statistik/laporanprofil-industri perbankan/Documents/LAPORAN\%20PROFIL\%20INDUSTRI\%20P 
ERBANKAN\%20TRIWULAN\%20II\%202020.pdf, akses tanggal 5 Maret 2021.

https://www.ojk.go.id/id/kanal/syariah/data-dan-statistik/laporanperkembangan-keuangan-syariahindonesia/Documents/LAPORAN\%20PERKEMBANGAN\%20KEU ANGAN\%20SYARIAH\%20INDONESIA \%202019.pdf, akses tanggal 5 Maret 2021. 